\title{
Pantoea ananatis Utilizes a Type VI Secretion System for Pathogenesis and Bacterial Competition
}

\author{
Divine Y. Shyntum, ${ }^{1,2}$ Jacques Theron, ${ }^{1}$ Stephanus N. Venter, ${ }^{1,2}$ Lucy N. Moleleki, ${ }^{1,2}$ Ian K. Toth, ${ }^{2,3}$ \\ and Teresa A. Coutinho, ${ }^{1,2}$ \\ ${ }^{1}$ Department of Microbiology and Plant Pathology, Faculty of Natural and Agricultural Sciences, and ${ }^{2}$ Forestry and Agricultural \\ Biotechnology Institute (FABI), University of Pretoria, Pretoria 0002, South Africa; ${ }^{3} J a m e s$ Hutton Research Institute, \\ Invergowrie, Dundee DD2 5DA, Scotland, United Kingdom
}

Submitted 26 July 2014. Accepted 7 November 2014.

\begin{abstract}
Type VI secretion systems (T6SSs) are a class of macromolecular machines that are recognized as an important virulence mechanism in several gram-negative bacteria. The genome of Pantoea ananatis LMG $2665^{\mathrm{T}}$, a pathogen of pineapple fruit and onion plants, carries two gene clusters whose predicted products have homology with T6SS-associated gene products from other bacteria. Nothing is known regarding the role of these T6SS-1 and T6SS-3 gene clusters in the biology of $P$. ananatis. Here, we present evidence that T6SS-1 plays an important role in the pathogenicity of $P$. ananatis LMG $2665^{\mathrm{T}}$ in onion plants, while a strain lacking T6SS-3 remains as pathogenic as the wild-type strain. We also investigated the role of the T6SS-1 system in bacterial competition, the results of which indicated that several bacteria compete less efficiently against wild-type LMG $2665^{T}$ than a strain lacking T6SS-1. Additionally, we demonstrated that these phenotypes of strain LMG $2665^{\mathrm{T}}$ were reliant on the core T6SS products TssA and TssD (Hcp), thus indicating that the T6SS-1 gene cluster encodes a functioning T6SS. Collectively, our data provide the first evidence demonstrating that the T6SS-1 system is a virulence determinant of $P$. ananatis LMG $2665^{\text {T }}$ and plays a role in bacterial competition.
\end{abstract}

Secretion of proteins such as extracellular proteases and toxins can provide selective advantages to bacteria in various environmental niches, and many of the proteins secreted by pathogenic bacteria are important colonization and virulence factors. To date, six types of protein secretion systems (type I through type VI secretion systems [T1SS through T6SS]) have been described in gram-negative bacteria (Economou et al. 2006; Holland 2010). These secretion systems are distinguished by the conserved structural components that define them, as well as the characteristics of their substrates and the molecular mechanisms underlying the export process. The most recently described T6SS has emerged as having a role in bacterial pathogenesis and host interactions (Coulthurst 2013; Kapitein and Mogk 2013). Data from structural studies, functional assays, and protein localization studies suggest that the T6SS consists of a membrane-associated assembly platform and

Corresponding author: T. A. Coutinho; Telephone: +27 12 420-3934; Fax: +27 12 420-3960; E-mail: Teresa.Coutinho@up.ac.za

*The $e$-Xtra logo stands for "electronic extra" and indicates that one supplementary figure and two supplementary tables are published online.

(C) 2015 The American Phytopathological Society a cell surface-exposed needle structure that transports effector molecules into bacteria or eukaryotic cells (Filloux et al. 2008; Silverman et al. 2012).

Whole-genome analyses have predicted T6SS gene clusters to be widely distributed in gram-negative bacterial species (Bingle et al. 2008; Boyer et al. 2009). Although the T6SS gene clusters differ between bacterial species in terms of gene order and composition, they comprise at least 13 core genes (type VI secretion $[t s s]$, nomenclature proposed by Shalom and associates [2007]) and a variable number of nonconserved accessory elements that encode the T6SS "injectisome" (Bingle et al. 2008; Cascales 2008). A number of the T6SS core proteins are evolutionary and structurally related to bacteriophage proteins (Kanamaru 2009; Leiman et al. 2009). Examples are the baseplate gp25-like protein TssE, the tail sheath-like proteins TssB and TssC, the tail subunit-like hemolysin coregulated protein (Hcp; TssD) that polymerizes into the T6SS needle structure, and the valine-glycine repeat protein $\mathrm{G}$ (VgrG; TssI) that forms the spike of the TssD nanotube (Ballister et al. 2008; Cascales and Cambillau 2012; Lossi et al. 2011, 2013; Pukatzki et al. 2007). Contraction and extension of the TssB-TssC tubular sheath of the T6SS of Vibrio cholerae have been visualized in vivo, suggesting that the T6SS sheath is a dynamic contractile structure that projects the T6SS spike into the target cell analogous to the bacteriophage infection process (Basler et al. 2012). Disassembly of the contracted sheath requires the ClpV (TssH) AAA+ ATPase, which binds specifically to the contracted TssB-TssC sheath for its disassembly and cycling (Bönemann et al. 2009; Kapitein et al. 2013). Another group of T6SS building blocks (TssM-L) appears to be related to proteins of the T4SS (Durand et al. 2012; Felisberto-Rodrigues et al. 2011) and may be involved in the recruitment of TssD (Hcp) to the T6SS inner membrane assembly platform (Ma et al. 2012).

The T6SSs have been implicated in a variety of functions ranging from biofilm formation to host-cell invasion, cytotoxicity, and survival in macrophages (Aschtgen et al. 2008; Cascales 2008; Schwarz et al. 2010a). However, most studies of the T6SS have focused on its role in pathogenesis and host interactions. The T6SS has been implicated as a virulence factor in several human or animal pathogens, including $V$. cholerae (Pukatzki et al. 2006), Pseudomonas aeruginosa (Mougous et al. 2006), Burkholderia mallei (Schell et al. 2007), Aeromonas hydrophila (Suarez et al. 2008), Edwardsiella tarda (Zheng and Leung 2007), Salmonella enterica serovar Gallinarum (Blondel et al. 2010), and avian pathogenic Escherichia coli (de Pace et al. 2010). It has subsequently been revealed that some T6SSs are used to target other bacteria, efficiently killing or inhibiting 
the growth of competitors, as reported for T6SSs of Serratia marcescens (Murdoch et al. 2011), P. aeruginosa (Hood et al. 2010), B. thailandensis (Schwarz et al. 2010b), and V. cholerae (MacIntyre et al. 2010). In contrast to animal and human pathogens, the role of T6SSs in plant bacterial pathogens is still largely unknown (Records, 2011). Nevertheless, T6SS functionality has been demonstrated for a few plant-associated bacteria, including Agrobacterium tumefaciens (Lin et al. 2013; Wu et al. 2008), Pectobacterium atrosepticum (Liu et al. 2008), and Pseudomonas syringae (Haapalainen et al. 2012), and it was recently reported that the T6SS of $P$. fluorescens plays an important role in bacterial competition (Decoin et al. 2014).

Pantoea ananatis is a gram-negative bacterial pathogen of plants. It causes disease in a wide variety of economically important plants such as Eucalyptus spp., Sudangrass, cotton, rice, corn, onion, melon, cantaloupe fruit, and pineapple (Coutinho and Venter 2009). Diseases caused by $P$. ananatis in onion, for example, result in reductions in crop yield, thus leading to substantial economic losses (Gitaitis and Gay 1997; Goszczynska et al. 2007; Walcott et al. 2002). To date, there are a limited number of reports that focus on the mechanisms by which P. ananatis causes disease (Morohoshi et al. 2007, Morohoshi et al. 2011a,b; Sessitsch et al. 2004). Consequently, the pathogenesis of $P$. ananatis is still poorly understood and the potential virulence determinants and mechanisms employed by $P$. ananatis have yet to be defined. Comparative genomic analysis of Pantoea spp. have demonstrated the presence of up to three gene clusters, designated T6SS-1 through T6SS-3, encoding components of the T6SS (De Maayer et al. 2011). Subsequent comparative genomics of sequenced $P$. ananatis strains indicated that the T6SS-1 and T6SS-3 gene clusters are present in all strains analyzed, whereas the T6SS-2 gene cluster is present in some but not all of these strains (Shyntum et al. 2014). It is currently not known whether these gene clusters are functionally redundant or are required for a specific activity.

In this study, we made use of a targeted mutagenesis strategy to evaluate the T6SS-1 and T6SS-3 gene clusters, present in the genome of $P$. ananatis LMG $2665^{\mathrm{T}}$, for a role in pathogenesis and competitiveness. The results indicate that T6SS-1 is an important virulence determinant of $P$. ananatis LMG $2665^{\mathrm{T}}$ and plays a role in intra- and interspecies bacterial competition.

\section{RESULTS}

\section{Construction of T6SS gene cluster deletions} in $P$. ananatis LMG $2665^{\mathrm{T}}$.

Previous sequence analyses demonstrated the presence of two gene clusters in the genome of $P$. ananatis LMG $2665^{\mathrm{T}}$ that contain genes homologous to those present in T6SSs (Shyntum et al. 2014). The 40.6-kb T6SS-1 gene cluster contains genes that are predicted to encode the 13 core T6SS proteins (TssA-M), five proteins associated with T6SSs in other bacteria (Tag), and 18 proteins that are present in very few or no other systems. In contrast, the 8.4-kb T6SS-3 gene cluster encodes two proteins (TssM and TssL) that are conserved in T6SSs and four accessory proteins (Fig. 1). No genetic analysis of these loci has been performed previously, and the function of the proteins encoded in these loci has also not yet been explored. Thus, we began by deleting the individual putative T6SS loci of $P$. ananatis LMG $2665^{\mathrm{T}}$. In this study, we used the $\lambda$ Red-recombineering technique (Datsenko and Wanner 2000) to delete the gene clusters and replace them with a kanamycin resistance cassette, yielding strains $2665^{\mathrm{T}} \Delta \mathrm{T} 6 \mathrm{SS}-1$ and $2665^{\mathrm{T}} \Delta \mathrm{T} 6 \mathrm{SS}-3$, respectively. The growth curves of the wild-type LMG $2665^{\mathrm{T}}$ strain and the mutant strains in Luria Bertani (LB) broth and in planta were similar (Fig. 2),

\section{T6SS-1 gene cluster}

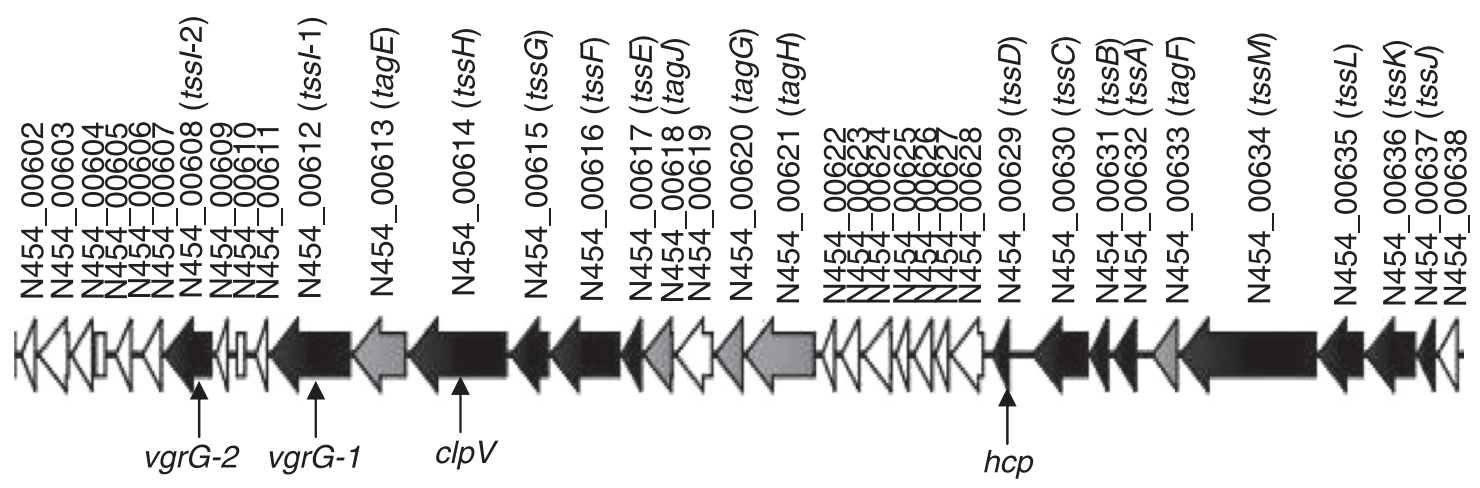

T6SS-3 gene cluster

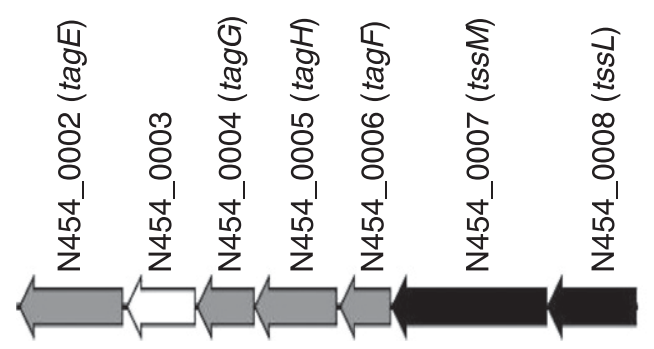

Fig. 1. Putative T6SS gene clusters of Pantoea ananatis LMG $2665^{\mathrm{T}}$. Genes (indicated with locus names) with homology to conserved core T6SS components are designated as type VI secretion (tss) and indicated in black, whereas genes associated with T6SSs of several bacteria are designated as type VI secretionassociated gene (tag) and indicated in gray. The nomenclature is based on that proposed by Shalom and associates (2007). 


\section{A}

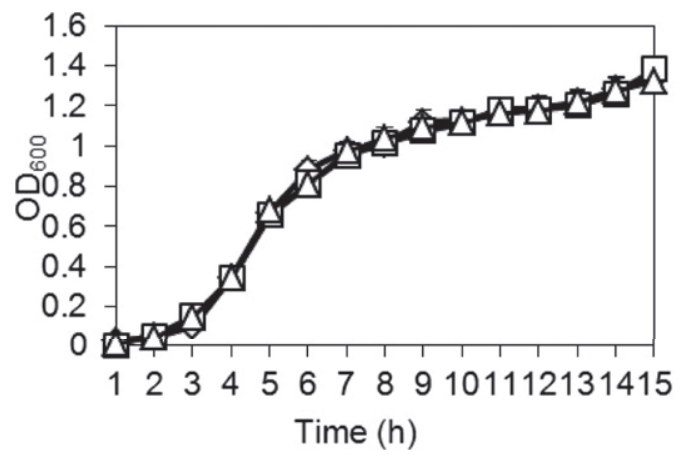

B

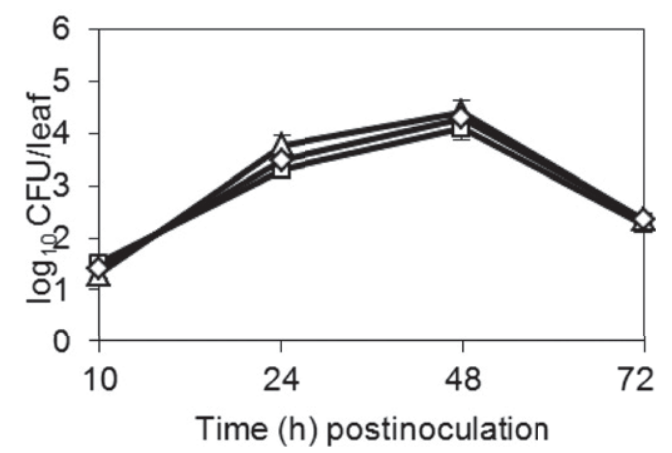

\section{$\triangle=$ LMG $2665^{\top} \quad \square=2665^{\top} \Delta$ T6SS $-1 \quad \diamond=2665^{\top} \Delta$ T6SS-3}

Fig. 2. Growth of Pantoea ananatis wild-type LMG $2665^{\mathrm{T}}$ and mutant strains lacking the T6SS-1 or T6SS-3 gene clusters. A, Strains were cultured in Luria Bertani (LB) broth at $32^{\circ} \mathrm{C}$ and growth was monitored for $15 \mathrm{~h}$ at an optical density at $600 \mathrm{~nm}\left(\mathrm{OD}_{600}\right)$. B, Prior to in planta growth determination, the $P$. ananatis wild-type and mutant strains were transformed with plasmid pMP7605 to confer gentamycin resistance. Onion leaves were inoculated with $10^{3}$ bacteria of the derivative wild-type and mutant strains, and the plants were incubated in a greenhouse at 28 to $30^{\circ} \mathrm{C}$. At the indicated times postinoculation, leaves were cut and homogenized and the CFU determined by plating on LB agar medium with antibiotic. In both A and B, results are presented as the mean of three independent experiments and the error bars represent the standard error of the mean.
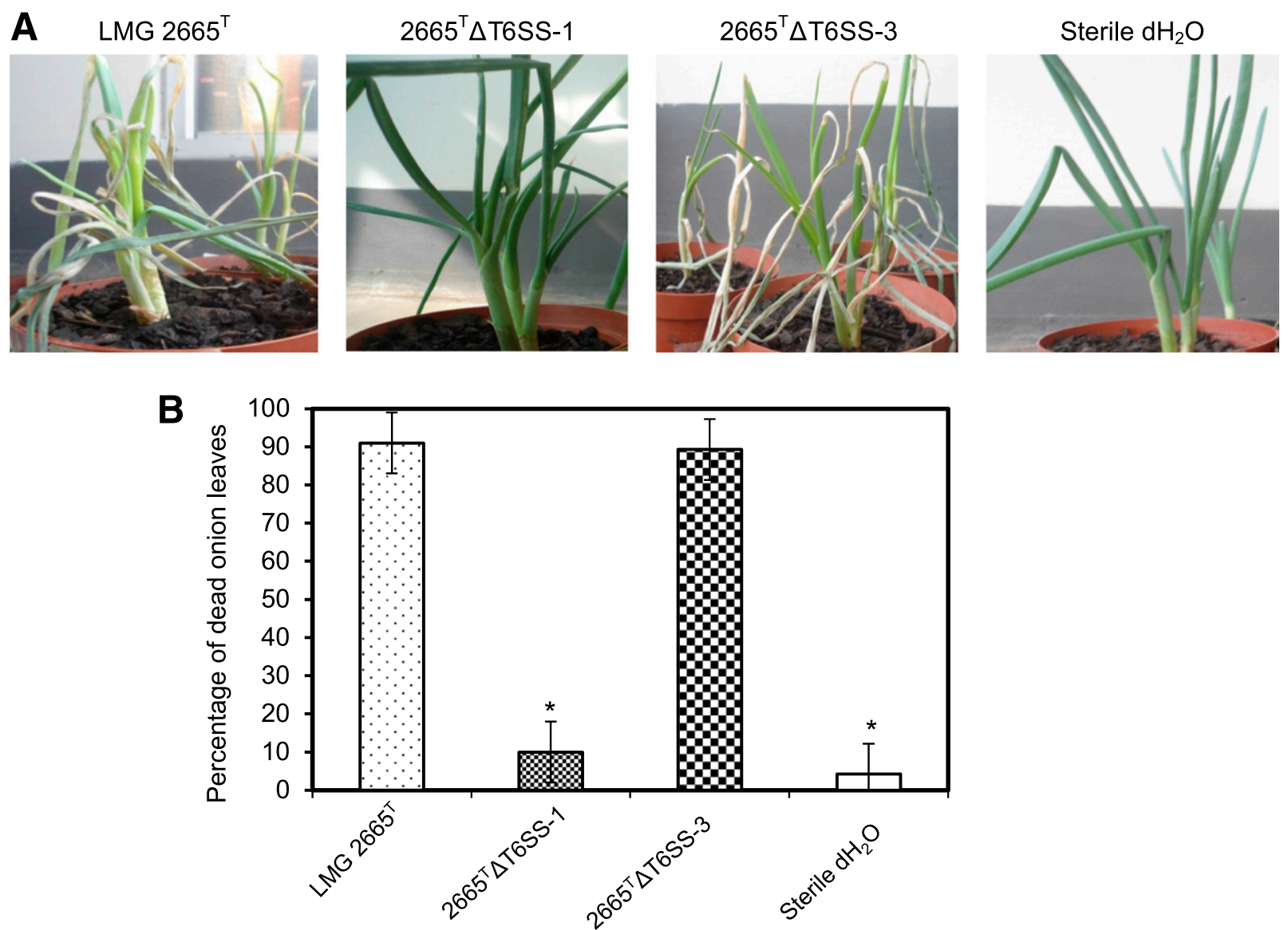

Bacterial strains

Fig. 3. Pathogenicity of Pantoea ananatis wild-type LMG $2665^{\mathrm{T}}$ and mutant strains lacking the T6SS-1 or T6SS-3 gene clusters. The leaves of 6-week-old onion plants were inoculated with $10^{3}$ bacteria at one site per leaf and the plants were incubated in a greenhouse for 3 days. In these assays, plants inoculated with sterile distilled water $\left(\mathrm{dH}_{2} \mathrm{O}\right)$ were included as a negative control. Three individual experiments, each containing at least 20 plants per treatment, were performed. A, Disease symptoms of onion plants inoculated with the P. ananatis strains. Pictures were taken at 3 days postinoculation and indicate representative results. B, At 3 days postinoculation, the number of inoculated wilted (dead) leaves per onion plant was recorded and the percentage of dead leaves was calculated. Data represent the mean percentage of dead leaves from the three biological repeats and error bars represent the standard error of the mean. Statistically significant differences between $P$. ananatis LMG $2665^{\mathrm{T}}$ and the respective mutant strains was determined by an unpaired, two-tailed Student's $t$ test, and are indicated by asterisks. 
indicating that deletion of the respective gene clusters did not alter growth kinetics.

\section{The T6SS-1 of $P$. ananatis LMG $2665^{\mathrm{T}}$ is required} for pathogenesis in onion plants.

To determine whether the T6SS gene clusters play a role in the biology of $P$. ananatis, we assessed the ability of mutants lacking the T6SS-1 or T6SS-3 gene clusters to cause disease by conducting pathogenicity tests on susceptible onion plants. The wild-type strain LMG $2665^{\mathrm{T}}$ and its mutants were inoculated into onion leaves and the development of disease symptoms was monitored. Although the $2665^{\mathrm{T}} \Delta \mathrm{T} 6 \mathrm{SS}-1$ mutant strain did not induce any disease symptoms, onion leaves infected with the wildtype LMG $2665^{\mathrm{T}}$ strain or the $2665^{\mathrm{T}} \Delta \mathrm{T} 6 \mathrm{SS}-3$ mutant strain developed symptoms typical of disease caused by $P$. ananatis in onion plants. Initially, the onion leaves infected with strain LMG $2665^{\mathrm{T}}$ or $2665^{\mathrm{T}} \Delta \mathrm{T} 6 \mathrm{SS}-3$ developed water-soaked spots on the sites of inoculation, which was followed by complete collapse of the infected leaves, necrosis, wilting, and then death (Fig. 3A). At 3 days postinoculation, the number of wilted (dead) leaves per plant for each strain was recorded and the average percentage of dead leaves calculated. On average, the mutant $2665^{\mathrm{T}} \Delta \mathrm{T} 6 \mathrm{SS}-1$ strain was significantly $(P<0.05)$ reduced in virulence compared with the wild-type LMG $2665^{\mathrm{T}}$ strain, whereas the mutant $2665^{\mathrm{T}} \Delta \mathrm{T} 6 \mathrm{SS}-3$ strain retained virulence levels similar to those of the wild-type strain (Fig. 3B). These data demonstrate that the pathogenicity of $P$. ananatis LMG $2665^{\mathrm{T}}$ is dependent on the presence of the T6SS-1 but not the T6SS-3 gene cluster.
The T6SS-1 of $P$. ananatis LMG $2665^{\mathrm{T}}$ is used to compete against different gram-negative bacteria.

An increasing number of T6SSs have been linked to interbacterial killing of gram-negative bacteria through the delivery of different toxins that target the peptidoglycan of susceptible bacterial species (Carruthers et al. 2013; English et al. 2012; Hood et al. 2010; Russell et al. 2011). To determine whether $P$. ananatis LMG $2665^{\mathrm{T}}$ displays antibacterial activity and also to explore the scope of the potential antibacterial activity, an in vitro competition assay was performed. The wild-type LMG $2665^{\mathrm{T}}$ strain was initially tested against a panel of 30 gramnegative bacteria, including $E$. coli, which has previously been shown to be susceptible to T6SS killing (MacIntyre et al. 2010; Weber et al. 2013; Zheng et al. 2011). Gram-positive bacteria (Bacillus spp. and B. cereus) were included in the assay as controls (Supplementary Table S2). The wild-type LMG $2665^{\mathrm{T}}$ strain was virulent toward various gram-negative bacteria but did not display antimicrobial activity toward any of the grampositive bacteria tested (data not shown). The antibacterial activity of the LMG $2665^{\mathrm{T}}$ strain was limited to E. coli DH5 $\alpha$, Pectobacterium carotovorum subsp. carotovorum LMG $2404^{\mathrm{T}}$, Salmonella enterica serovar Typhimurium, Pantoea stewartii subsp. indologenes, and two strains of P. ananatis (LMG 2669 and LMG 2664). These gram-negative bacteria were used in all subsequent competition experiments.

To test the contribution of the T6SS gene clusters to the antibacterial properties of $P$. ananatis LMG $2665^{\mathrm{T}}$, we examined whether the mutants lacking the T6SS-1 or T6SS-3 gene

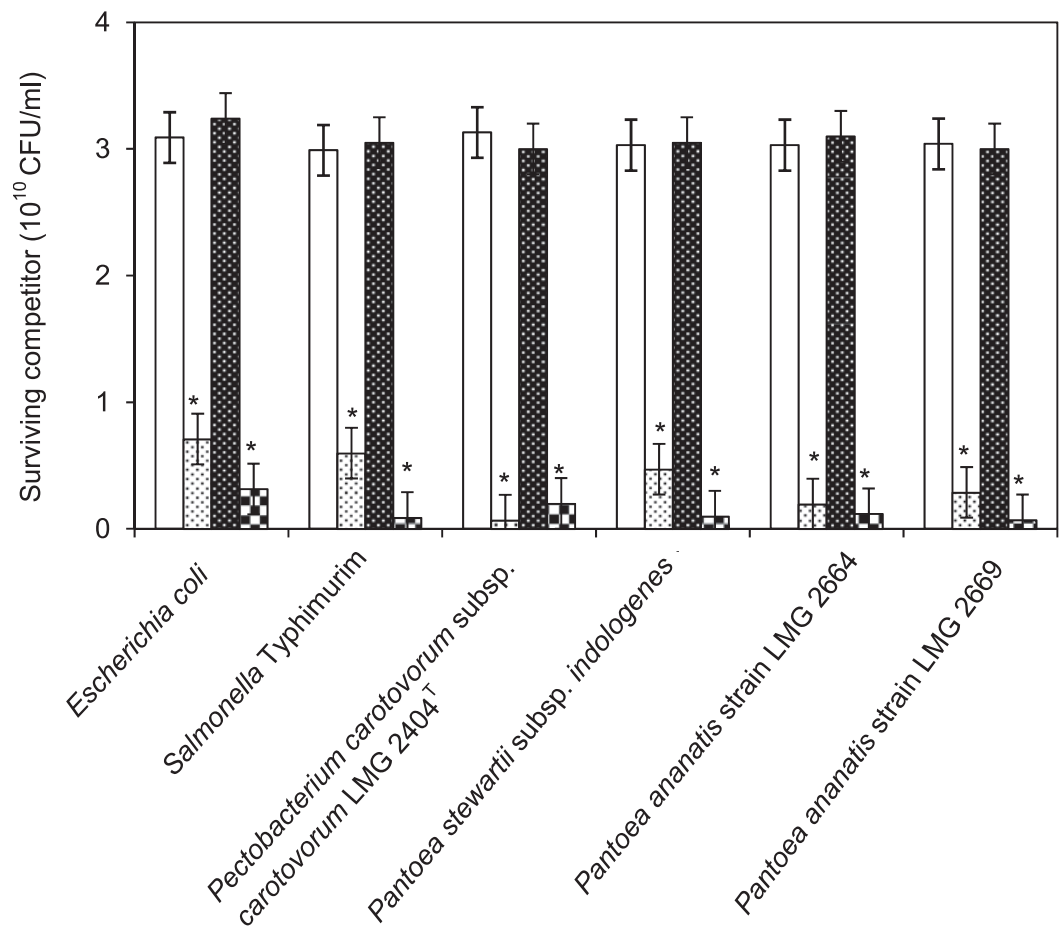

Competitor bacteria

$$
=\text { no-treatment control }=\text { LMG } 2665^{\top} \gg=2665^{\top} \Delta \text { T6SS-1 } \quad 0=2665^{\top} \Delta \text { T6SS-3 }
$$

Fig. 4. The T6SS-1 of Pantoea ananatis wild-type LMG $2665^{\mathrm{T}}$ is used for antibacterial activity. The $P$. ananatis wild-type or $2665^{\mathrm{T}} \Delta \mathrm{T} 6 \mathrm{SS}-1$ or $2665^{\mathrm{T}} \Delta \mathrm{T} 6 \mathrm{SS}-3$ mutant strains were mixed with a gentamycin-resistant bacterium at a ratio of 1:1 and spotted onto Luria Bertani (LB) agar. After overnight incubation, spots were recovered and survivor competitor bacterial cells were assessed by spreading dilutions on LB agar with antibiotic and CFU determination. Data represent the mean $\mathrm{CFU} / \mathrm{ml}$ from three independent experiments and error bars represent the standard error of the mean. The CFU/ml of competitor bacteria was significantly reduced in competition assays with strains LMG $2665^{\mathrm{T}}$ and $2665^{\mathrm{T}} \Delta \mathrm{T} 6 \mathrm{SS}-3(P<0.05$; unpaired, two-tailed Student's $t$ test) but not with strain $2665^{\mathrm{T}} \Delta \mathrm{T} 6 \mathrm{SS}-1$ when compared with the no-treatment controls. Statistically significant differences are denoted with asterisks. 
clusters could reduce the numbers of the above bacteria when grown in competition on agar plates. When each competitor strain was cocultured with wild-type LMG $2665^{\mathrm{T}}$ or the $2665^{\mathrm{T}} \Delta \mathrm{T} 6 \mathrm{SS}-3$ mutant strain, there was a significant $(P<0.05)$ drop in the number of viable cells recovered (10- to 100 -fold) compared with results for the no-treatment controls. However, when the coculture was with $2665^{\mathrm{T}} \Delta \mathrm{T} 6 \mathrm{SS}-1$, the survival of competitor bacteria was increased up to 100 -fold compared with that of wild-type LMG $2665^{\mathrm{T}}$ or $2665^{\mathrm{T}} \Delta \mathrm{T} 6 \mathrm{SS}-3$ (Fig. 4). Overall, the results suggest that the T6SS-1 gene cluster provides $P$. ananatis LMG $2665^{\mathrm{T}}$ with a competitive advantage toward selected gram-negative bacteria.

\section{Construction of $t s s A$ and $t s s D(h c p)$ mutants of $P$. ananatis LMG $2665^{\mathrm{T}}$.}

To determine whether $P$. ananatis $\mathrm{LMG} 2665^{\mathrm{T}}$ produces a functioning T6SS, we selected the $t s s A$ and $t s s D(h c p)$ genes present in the T6SS-1 gene cluster for mutational analyses. TssD (Hcp), a "hallmark" of T6SSs (Bingle et al. 2008), forms hexameric rings that polymerize into tubules. It is believed that these nanotubes are extruded following contraction of the surrounding TssB-TssC sheath, thereby facilitating transport of T6SS-dependent effector proteins across membranes of target cells (Ballister et al. 2008; Basler et al. 2012; Jobichen et al. 2010). TssA is predicted to be a cytoplasmic protein and contains an ImpA-like domain of unknown function (Cascales and Cambillau 2012). It has been speculated that TssA plays a regulatory role or is associated with proteins destined for secretion (Shrivastava and Mande 2008). The P. ananatis LMG $2665^{\mathrm{T}}$ mutant strains were constructed by replacement of the selected genes with a kanamycin-resistant cassette, yielding strains $2665^{\mathrm{T}} \Delta t s s A$ and $2665^{\mathrm{T}} \Delta t s s D$, respectively. As expected from deletion of the entire T6SS-1 cluster (see above), deletion of the $t s s A$ or $t s s D$ genes did not have any detectable impact on growth in vitro and in planta (data not shown).

\section{The T6SS-1 of $P$. ananatis LMG $2665^{\mathrm{T}}$ encodes a functioning T6SS.}

To determine the effects of the $t s s A$ and $t s s D$ gene deletions on T6SS-1 activity, we examined each mutant strain for its contribution to pathogenicity in onion plants and antibacterial activity. The pathogenicity of the $2665^{\mathrm{T}} \Delta t s s A$ and $2665^{\mathrm{T}} \Delta t s s D$ mutant strains was compared with the wild-type LMG $2665^{\mathrm{T}}$ strain by conducting pathogenicity tests on onion leaves, as described above. The results indicated that, in contrast to the wild-type strain, neither of the mutant strains induced disease (Figs. 5A and $5 \mathrm{~B}$ ). We also repeated the bacterial competition assay with the gram-negative bacterial strains previously shown to be susceptible to T6SS-1-dependent antibacterial activity. After competition with the wild-type strain LMG $2665^{\mathrm{T}}$, a 10 - to 100 -fold reduction $(P<0.05)$ in bacteria was observed after coculture, while surviving bacterial populations from competitions with $2665^{\mathrm{T}} \Delta t s s A$ and $2665^{\mathrm{T}} \Delta t s s D$ were equivalent to no-treatment controls (Fig. 5C). To directly link the phenotypes observed for the $2665^{\mathrm{T}} \Delta t s s A$ and $2665^{\mathrm{T}} \Delta t s s D$ mutant strains to T6SS-1 functionality, the respective mutant strains were transformed with a plasmid harboring a wild-type copy of the $t s s A$ or $t s s D$ genes. Introduction of the $t s s A$ and $t s s D$ genes in trans restored the activity of the $2665^{\mathrm{T}} \Delta t s s A$ and $2665^{\mathrm{T}} \Delta t s s D$ strains to cause disease in onion plants and to compete with bacteria (Fig. 5), thus demonstrating that the mutations are not polar and that these genes are required to produce a functional T6SS apparatus in $P$. ananatis LMG $2665^{\mathrm{T}}$.

\section{DISCUSSION}

Protein secretion systems are often critical to the virulence and host-interaction processes of gram-negative bacterial pathogens (Gerlach and Hensel 2007). Among the different secretion systems, the T2SS secretes proteins from the bacteria to the exterior to degrade host cell components (Cianciotto 2005; Sandkvist 2001), whereas T3SS and T4SS transfer effectors directly from the bacteria into host cells and, consequently, manipulate the host response for their own benefit (Backert and Meyer 2006; Cornelis 2006; Hueck 1998). Despite its ability to cause disease in a wide variety of economically important crops, $P$. ananatis lacks genes homologous to the above-mentioned secretion systems (De Maayer et al. 2011). Thus, the strategy and mechanisms that contribute to infection and disease development are poorly understood in this plant pathogen. Notably, T6SS-associated genes have been identified in Pantoea spp. (De Maayer et al. 2011) and P. ananatis (Shyntum et al. 2014) specifically. In the case of $P$. ananatis LMG $2665^{\mathrm{T}}$, the T6SS-associated genes are located in two clusters, named as T6SS-1 and T6SS-3, respectively. Considering that T6SSs have been implicated in promoting virulence and cytotoxicity in eukaryotic and bacterial hosts (Kapitein and Mogk 2013; Schwarz et al. 2010a), this has generated several questions as to whether the respective gene clusters in $P$. ananatis encode a functional T6SS and whether these T6SSs may play similar roles in the biology of $P$. ananatis LMG $2665^{\mathrm{T}}$.

Pathogenicity assays in onion plants performed with $P$. ananatis LMG $2665^{\mathrm{T}}$ mutant strains lacking the T6SS-1 or T6SS-3 gene clusters showed that mutant strain $2665^{\mathrm{T}} \Delta \mathrm{T} 6 \mathrm{SS}-3$ was as pathogenic as the wild-type LMG $2665^{\mathrm{T}}$ strain, whereas mutant strain $2665^{\mathrm{T}} \Delta \mathrm{T} 6 \mathrm{SS}-1$ was not pathogenic. These results indicate that the T6SS-1 gene cluster likely encodes a functional T6SS that has an essential role in pathogenicity. Although the truncated T6SS-3 gene cluster, which lacks 11 of the core T6SS genes, appears not to play a role in either pathogenicity or antibacterial competition and, therefore, may not encode a functional T6SS, it is intriguing to understand why this cluster is maintained. Its $100 \%$ prevalence among $P$. ananatis strains (Shyntum et al. 2014) suggests that this seemingly stable gene cluster may be advantageous to the bacteria for an as-yet-unknown function.

It is interesting to note that the T6SS-3 gene cluster is predicted to encode homologs of Fha (TagH), PpkA (TagE), and PppA (TagG), which have been implicated in the regulation of T6SS activity by a posttranslational protein phosphorylation mechanism. In $P$. aeruginosa, Fha is phosphorylated by the serine-threonine kinase PpkA and dephosphorylated by the phosphatase PppA, and the phosphorylation of Fha regulates

Fig. 5. Phenotypic analysis of Pantoea ananatis LMG $2665^{\mathrm{T}}$ mutant strains lacking the T6SS-1 gene cluster genes $t s s A$ and $t s s D$. A, Disease symptoms of onion plants inoculated with the wild-type LMG $2665^{\mathrm{T}}$, mutant, or complemented mutant strains. Representative pictures, taken at 3 days postinoculation, are shown. B, Virulence of the wild-type and complemented mutant strains was not significantly different, although these strains differed significantly from the mutant strains. Bars represent the mean percentage of dead of onion leaves from three individual experiments, each containing at least 20 plants per treatment, and error bars represent the standard error of the mean. Statistically significant differences between the $P$. ananatis strains were determined by an unpaired, two-tailed Student's $t$ test, and are indicated by asterisks. C, In bacterial competition assays, the survival of competitor bacteria was determined by measuring the corresponding $\mathrm{CFU}$ after exposure to either the wild-type, mutant, or complemented mutant strains of $P$. ananatis LMG $2665^{\mathrm{T}}$. Data represent $\mathrm{CFU} / \mathrm{ml}$ from three independent experiments. Bars represent mean values and error bars denote the standard error of the mean. Statistically significant differences between the respective $P$. ananatis LMG $2665^{\mathrm{T}}$ strains and the no-treatment controls were determined by an unpaired, two-tailed Student's $t$ test, and are indicated by asterisks. 
A

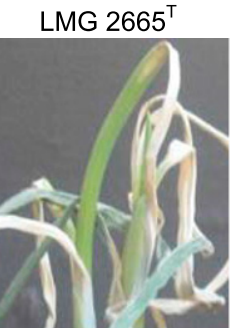

$2665^{\top} \Delta t s s A$

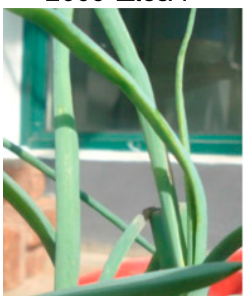

$2665^{\top} \Delta t s s A-c o m p l$

$2665^{\top} \Delta t s s D$

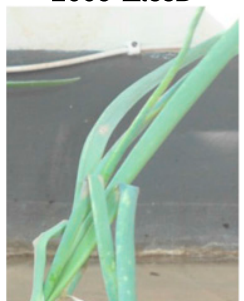

$2665^{\top} \Delta t s s D$-compl
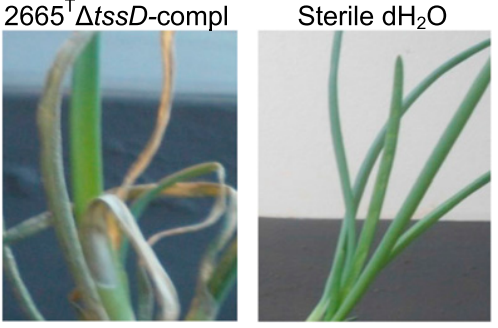

B

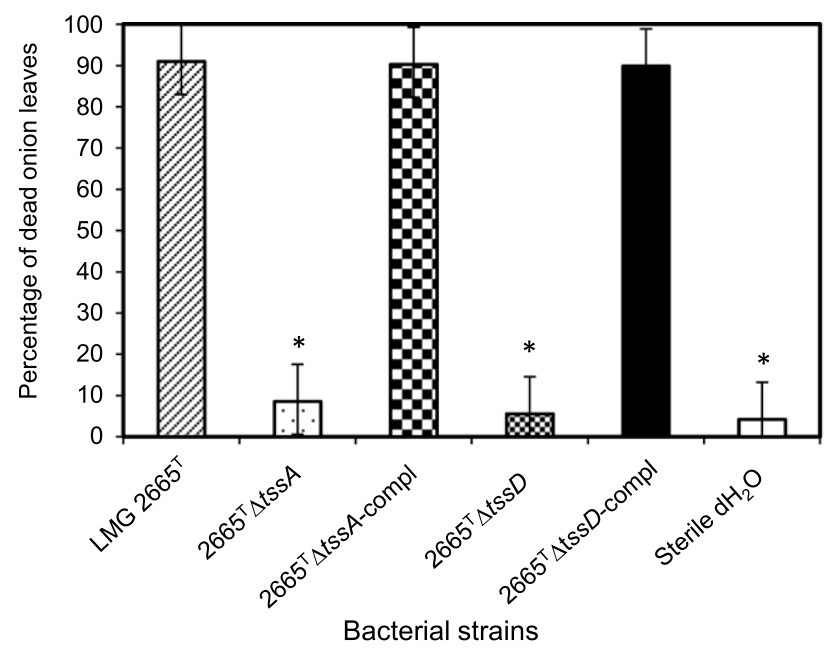

C

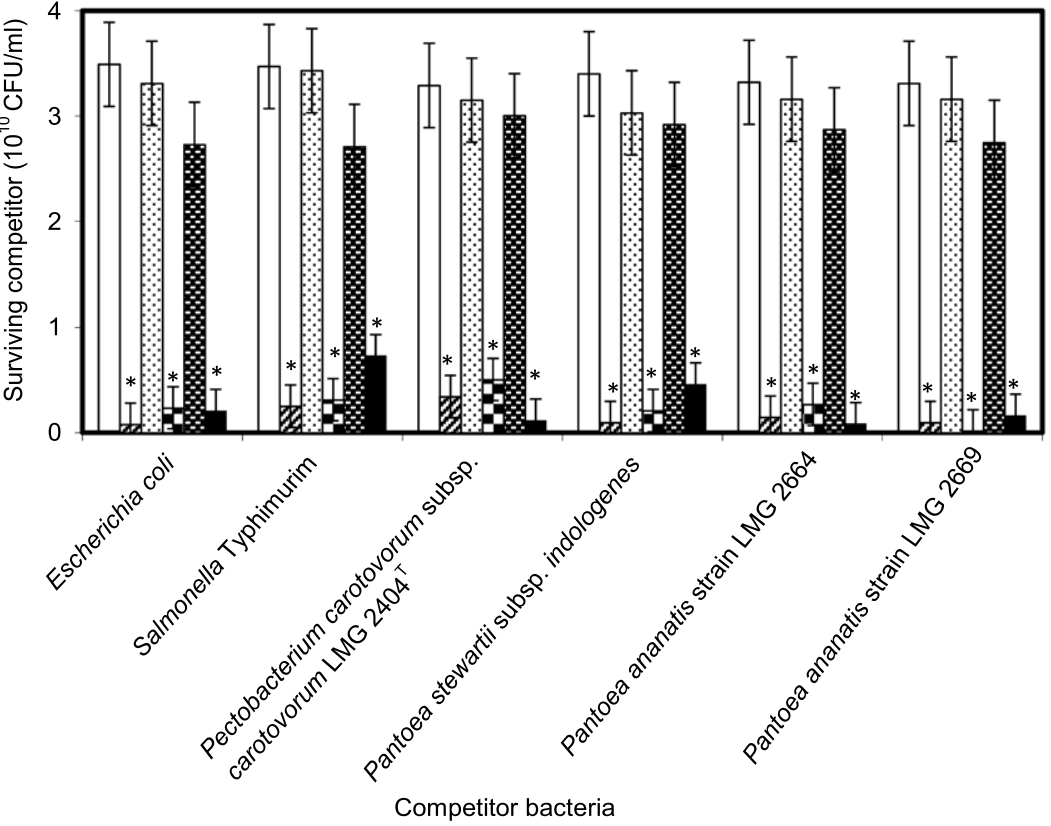

\footnotetext{
$\square=$ no-treatment control $\square=$ LMG $2665^{\top} \quad \square=2665^{\top} \Delta t s s A \quad \square=2665^{\top} \Delta$ tssA-compl

$\otimes=2665^{\top} \Delta t s s D \quad \square=2665^{\top} \Delta t s s D$-compl
} 
the activity of the T6SS (Mougous et al. 2007). Considering that these posttranslational regulatory components are also encoded by the T6SS- 1 gene cluster of $P$. ananatis LMG $2665^{\mathrm{T}}$, the implications of this potential redundancy are intriguing. It is tempting to speculate not only that activation of the T6SS-1 of strain LMG $2665^{\mathrm{T}}$ depends on a similar posttranslational mechanism but also that the products of the T6SS-3 gene cluster may contribute to differentially regulating T6SS-1 activity under different culture conditions. This may explain why the $P$. ananatis strains retain the truncated T6SS-3 gene cluster. Further work, however, will be required to clarify this hypothesis and to identify environmental signals that may be responsible for triggering the expression of the respective gene clusters.

Very little information is available about potential effector proteins that are secreted in a T6SS-dependent manner into eukaryotic cells (Miyata et al. 2011; Zheng and Leung 2007). In some cases, VgrG proteins can exert effector functions on eukaryotic cells. For these so-called evolved VgrG proteins, this function is typically associated with the presence of an additional C-terminal effector domain. Activities of these evolved VgrGs include cross-linking or ADP-ribosylation of actin in eukaryotic cells, thereby promoting host cell toxicity (Ma and Mekalanos 2010; Pukatzki et al. 2007; Suarez et al. 2010). The T6SS-1 gene cluster of $P$. ananatis LMG $2665^{\mathrm{T}}$ contains two VgrG (TssI) homologs (Fig. 1). The putative VgrG proteins lack C-terminal effector domains and, thus, are likely not essential for pathogenesis in onion plants. Indeed, in the case of Pseudomonas fluorescens pv. tomato, which also contains two VgrG homologs lacking recognizable evolved C-terminal domains, it was reported that the VgrG-1 and VgrG-2 deletion mutant strains had no effect on disease development in tomato or in Nicotiana benthamiana (Sarris et al. 2012). A recent study, however, suggested that adaptor proteins may be widely utilized to facilitate the recruitment of effectors to VgrG proteins via binding at the VgrG C terminus (Shneider et al. 2013). Therefore, it is conceivable that one or more such proteins may bind to the $\mathrm{C}$ terminus of the Pantoea ananatis LMG $2665^{\mathrm{T}} \mathrm{VgrG}$ proteins and recruit effectors. In this way, each complex, VgrG-1 or VgrG-2, together with their cognate effectors, might sit independently or alternatively at the tip of the TssD ( Hcp) nanotube structures. Thus, following contraction of the sheath, the T6SS-1 may be capable of delivering a multifunctional cargo or a multiple effector VgrG spike into the host cell in a single molecular translocation event. The effector proteins that may be secreted by the T6SS-1 of $P$. ananatis LMG $2665^{\mathrm{T}}$ remain to be elucidated. Nevertheless, several genes of unknown function and limited or no conservation with other T6SSs are present in the $P$. ananatis LMG $2665^{\mathrm{T}}$ T6SS-1 gene cluster. These genes may present candidates for system-specific effectors and will be studied in future.

$P$. ananatis LMG $2665^{\mathrm{T}}$ was also found to exhibit antibacterial activity. On the basis of the 33 species tested in antibacterial competition assays, the host range was found to be restricted to selected gram-negative bacteria. We subsequently investigated whether the T6SS-1 and T6SS-3 contribute to the antibacterial activity of strain LMG $2665^{\mathrm{T}}$. The results indicate that strain LMG $2665^{\mathrm{T}}$ does, indeed, require T6SS-1 but not T6SS-3 to inhibit competitor bacteria, because coculture with the wild-type or mutant $2665^{\mathrm{T}} \Delta \mathrm{T} 6 \mathrm{SS}-3$ strains resulted in lower recovery of viable bacteria compared with the mutant $2665^{\mathrm{T}} \Delta \mathrm{T} 6 \mathrm{SS}-1$ strain. The antibacterial activity of the $P$. ananatis LMG $2665^{\mathrm{T}}$ T6SS- 1 is seen during coculture on solid agar medium surfaces; therefore, it may be that the T6SS-1 system acts through cell-to-cell contact (Dong et al. 2013; MacIntyre et al. 2010). We hypothesize that the antibacterial activity of $P$. ananatis $\mathrm{LMG} 2665^{\mathrm{T}}$ could be mediated by T6SS-1-directed intoxication of other bacteria, with protein effectors as part of a toxin-immunity system. Therefore, by implication, strain LMG $2665^{\mathrm{T}}$ must itself possess a cognate immunity protein to prevent self intoxication, whereas strains lacking cognate immunity proteins are inhibited. A functional link between T6SSs and toxin-immunity systems has been established in Pseudomonas aeruginosa (Hood et al. 2010), B. thailandensis (Russell et al. 2012), Serratia marcescens (Chou et al. 2012; English et al. 2012), and V. cholerae (Dong et al. 2013). Bioinformatic analysis indicated that there are no obvious homologs to these toxins or immunity proteins in the genome of Pantoea ananatis LMG $2665^{\mathrm{T}}$, thus supporting the notion that this bacterium may use a unique sets of effector and immunity proteins.

Recently, Rhs-family proteins of the soft-rot pathogen Dickeya dadantii were reported to mediate interbacterial competition (Koskiniemi et al. 2013). Rhs proteins are characterized by sequence-diverse C-terminal regions and vary considerably between different strains of the same species. All rhs genes are closely linked to small downstream open reading frames that encode RhsI immunity proteins. These immunity proteins are also sequence diverse and only protect against their cognate Rhs toxins (Koskiniemi et al. 2013; Zhang et al. 2012). The Rhs proteins are secreted in a T6SS-dependent manner in both S. marcescens (Fritsch et al. 2013) and D. dadantii (Koskiniemi et al. 2013), suggesting that these proteins might constitute a new family of T6SS effectors. Interestingly, the genome of $P$. ananatis LMG $2665^{\mathrm{T}}$ harbors two rhs/rhsI loci that are both located immediately adjacent to the T6SS-1 gene cluster only. Notably, one of the Rhs proteins, designated RhsD-1 (N454_00601), contains a conserved DUF4237 domain of unknown function at the $\mathrm{C}$ terminus. Given that Rhs toxins are encoded adjacent to theT6SS-1 gene cluster and that they appear to be secreted in a T6SS-dependent manner, it seems likely that one or both of the RhsD proteins may also play a role in $P$. ananatis LMG $2665^{\mathrm{T}}$ pathogenesis. Indeed, RhsT from Pseudomonas aeruginosa was shown to be translocated into phagocytic cells, where it induces inflammasomemediated cell death (Kung et al. 2012). Moreover, Salmonella enterica ser. Typhimurium mutants lacking rhs were completely attenuated in pig and cattle models of infection (Chaudhuri et al. 2013). Taking all of the above into consideration, it is tempting to speculate that Pantoea ananatis LMG $2665^{\mathrm{T}}$ Rhs proteins are secreted in a T6SS-1-dependent manner and used as virulence factors against plant host cells, in addition to prokaryotes. Whether the Rhs-family proteins are indeed T6SS-1 effector proteins remains to be experimentally determined.

With the exception of $S$. enterica ser. Typhimurium, it is noteworthy that the gram-negative bacteria inhibited by P. ananatis LMG $2665^{\mathrm{T}}$ are plant pathogens. Pectobacterium carotovorum subsp. carotovorum is a pathogen of numerous vegetables, including, cucumber, onion, potato, and cabbage (Toth et al. 2003), while Pantoea stewartii subsp. indologenes has been isolated from symptomatic millet, pineapple, and onion (Mergaert et al. 1993), and the P. ananatis strains LMG 2669 and LMG 2664 were both isolated from symptomatic pineapple displaying brown and gray rot (unpublished data). Notably, $S$. enterica ser. Typhimurium, albeit not generally considered a plant pathogen, has been isolated from cantaloupe fruit (Gallegos-Robles et al. 2008) and is capable of internalizing tomato plants (Gu et al. 2011). Considering that both these plants are hosts of $P$. ananatis (Coutinho and Venter 2009), S. enterica ser. Typhimurium may constitute a plausible competitor for $P$. ananatis. Based on the finding that $P$. ananatis $\mathrm{LMG} 2665^{\mathrm{T}}$ uses its T6SS-1 not only for competition with other bacterial species but also for competition within its own species, it is likely that killing of these bacteria in such a selective manner would be highly relevant to the ability of $P$. ananatis LMG $2665^{\mathrm{T}}$ to mount a successful infection. The antibacterial T6SS-1 of strain LMG $2665^{\mathrm{T}}$ could be used as a means of competitive exclusion, thereby creating a niche that is favorable for infection. 
To determine whether the observed phenotypes are dependent on a functioning T6SS-1, we generated $t s s A$ and $t s s D$ (hcp) deletion mutants in the T6SS-1 gene cluster. These mutations led to attenuated pathogenesis in onion plants and antibacterial activity, while expression of TssA and TssD from a plasmid restored the wild-type strain LMG $2665^{\mathrm{T}}$ phenotypes. The results indicate that the observed phenotypes were caused by T6SS-1 activity. Because other studies have shown that TssD forms a nanotube that acts as a conduit to allow transport of T6SS-dependent effector proteins or protein complexes (Ballister et al. 2008; Leiman et al. 2009; Shneider et al. 2013), it is likely that deletion of $t s s D$ in $P$. ananatis LMG $2665^{\mathrm{T}}$ causes defects in the assembly of the secretion apparatus or in the secretion of T6SS-1-dependent effectors, either of which would likely compromise T6SS-1 functionality. Although the function of the cytoplasmic TssA protein is not known (Cascales and Cambillau 2012), it has been proposed that TssA may play a regulatory role (Shrivastava and Mande 2008). More recently, TssA was shown to interact with TssK, a cytoplasmic protein that is responsible for TssB-TssC sheath polymerization (Zoued et al. 2013). Thus, TssA may indirectly regulate the assembly of TssBTssC tubules through its interaction with TssK; however, this requires further investigation.

In conclusion, we report the presence of a functional T6SS (T6SS-1) in $P$. ananatis LMG $2665^{\mathrm{T}}$ and provide evidence assigning functions to this T6SS in pathogenesis and bacterial competition. Further studies are needed to identify genes involved in the assembly and the mechanism of secretion of the T6SS-1, including the detection of TssD (Hcp) secretion, as well as the nature of any effectors or toxins. This study has added to our understanding of how $P$. ananatis causes disease, and provides a new potential target for control of diseases caused by this plant pathogen.

\section{MATERIALS AND METHODS}

Bacterial strains, plasmids and growth conditions.

The bacterial strains and plasmids used in this study are listed in Table 1. All P. ananatis strains in this study were derived from wild-type strain LMG $2665^{\mathrm{T}}$. Bacterial strains were grown on LB agar or in LB broth at $32^{\circ} \mathrm{C}$ (P. ananatis) or $37^{\circ} \mathrm{C}$ (E. coli) with shaking at $250 \mathrm{rpm}$. For plasmid DNA selection and maintenance, the growth medium was supplemented with kanamycin $(50 \mu \mathrm{g} / \mathrm{ml})$, gentamycin $(20 \mu \mathrm{g} / \mathrm{ml})$, or chloramphenicol $(50 \mu \mathrm{g} / \mathrm{ml})$. The growth of $P$. ananatis wild-type and mutant strains was compared in LB broth. To prepare inoculum for plant inoculations, $P$. ananatis cultures grown overnight in LB broth were diluted 100-fold in fresh LB broth and the cultures were incubated until they reached an optical density at $600 \mathrm{~nm}\left(\mathrm{OD}_{600}\right)$ of 0.4 . The cells were harvested by centrifugation $\left(7,000 \times g, 3 \mathrm{~min}, 4^{\circ} \mathrm{C}\right)$ and suspended in sterile distilled water $\left(\mathrm{dH}_{2} \mathrm{O}\right)$ until an $\mathrm{OD}_{600}$ of 0.1 (approximately $6.2 \times 10^{6} \mathrm{CFU} / \mathrm{ml}$, as determined by $\mathrm{di}-$ lution plating).

\section{In planta growth curve assays.}

The growth of $P$. ananatis wild-type and mutant strains was compared in onion (Allium cepa 'Texas grando') which, in previous studies, has been shown to be an excellent experimental host for P. ananatis (Goszczynska et al. 2006; Morohoshi et al. 2007). To enable enumeration of the bacteria, the respective strains were electroporated with plasmid pMP7605 to confer gentamycin resistance prior to the preparation of inoculum as described above. Leaves of 6-week-old onion seedlings were used for inoculation. Each leaf was inoculated with $3 \mu \mathrm{l}$ of a standardized bacterial suspension $\left(6.2 \times 10^{6} \mathrm{CFU} / \mathrm{ml}\right)$ and the plants were incubated in a greenhouse at $28^{\circ} \mathrm{C}$. Leaves were collected at 10 to $72 \mathrm{~h}$ postinoculation, macerated in $2 \mathrm{ml}$ of Tris-EDTA buffer (10 mM Tris-Cl and $1 \mathrm{mM}$ EDTA, $\mathrm{pH} 8.0$ ), serially diluted in sterile $\mathrm{dH}_{2} \mathrm{O}$, and then plated in duplicate on LB agar supplemented with gentamycin.

\section{Recombinant DNA techniques.}

Molecular cloning techniques used in the construction of recombinant plasmids were carried out using standard procedures (Sambrook and Russell 2001). Restriction enzymes, calf intestine alkaline phosphatase, Klenow fragment of $E$. coli DNA polymerase I, and T4 DNA ligase (Roche Diagnostics, Mannheim, Germany) were used according to the manufacturer's protocols. Plasmid DNA was extracted from E. coli with a Zyppy Plasmid Miniprep kit, genomic DNA was isolated from $P$. ananatis strains with a Quick gDNA isolation kit, and restriction DNA fragments were purified from agarose gels by use of a Zymoclean Gel DNA Recovery kit (all kits obtained

Table 1. Bacterial strains and plasmids used in this study

\begin{tabular}{|c|c|c|}
\hline Strain or plasmid & Characteristics $^{\mathbf{a}}$ & Reference or source \\
\hline \multicolumn{3}{|l|}{ Strains } \\
\hline \multicolumn{3}{|l|}{ Escherichia coli } \\
\hline $\mathrm{DH} 5 \alpha$ & $\begin{array}{l}\mathrm{F}^{-} \text {recAl endA1 hsdR17 deoR thi-1 supE44 gyrA96 relA1 } \Delta(\text { lacZYA-argF }) \mathrm{U} 169 \lambda^{-} \\
{[\Phi 80 \mathrm{~d} \text { lacZAM15] }}\end{array}$ & Invitrogen \\
\hline \multicolumn{3}{|l|}{ Pantoea ananatis } \\
\hline LMG $2665^{\mathrm{T}}$ & Wild-type, virulent pineapple isolate & Serrano 1928 \\
\hline LMG $2665^{\mathrm{T}}$ (pRSFRedTER) & Derivative of Pantoea ananatis LMG $2665^{\mathrm{T}}$, transformed with pRSFRedTER, $\mathrm{Cm}^{\mathrm{r}}$ & This study \\
\hline LMG $2665^{\mathrm{T}}(\mathrm{pMP} 7605)$ & Derivative of $P$. ananatis LMG $2665^{\mathrm{T}}$, transformed with pMP7605, $\mathrm{Gm}^{\mathrm{r}}$ & This study \\
\hline $2665^{\mathrm{T}} \Delta \mathrm{T} 6 \mathrm{SS}-1$ & LMG $2665^{\mathrm{T}}$ T6SS-1 gene cluster deletion mutant, $\mathrm{Km}^{\mathrm{r}}$ & This study \\
\hline $2665^{\mathrm{T}} \Delta \mathrm{T} 6 \mathrm{SS}-3$ & LMG $2665^{\mathrm{T}}$ T6SS-3 gene cluster deletion mutant, $\mathrm{Km}^{\mathrm{r}}$ & This study \\
\hline $2665^{\mathrm{T}} \Delta t s s A$ & LMG $2665^{\mathrm{T}}$ tssA deletion mutant, $\mathrm{Km}^{\mathrm{r}}$ & This study \\
\hline $2665^{\mathrm{T}} \Delta t s s D$ & LMG $2665^{\mathrm{T}}$ tss $D(h c p)$ deletion mutant, $\mathrm{Km}^{\mathrm{r}}$ & This study \\
\hline $2665^{\mathrm{T}} \Delta t s s A$-compl & $2665^{\mathrm{T}} \Delta t s s A$ complemented with $\mathrm{pBRR}-t s s A, \mathrm{Km}^{\mathrm{r}}, \mathrm{Gm}^{\mathrm{r}}$ & This study \\
\hline $2665^{\mathrm{T}} \Delta t s s D$-compl & $2665^{\mathrm{T}} \Delta t s s D$ complemented with $\mathrm{pBRR}-t s s D, \mathrm{Km}^{\mathrm{r}}, \mathrm{Gm}^{\mathrm{r}}$ & This study \\
\hline \multicolumn{3}{|c|}{ 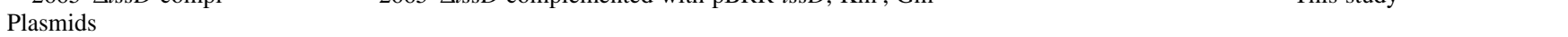 } \\
\hline pMP7605 & Broad-host-range cloning vector, $\mathrm{pBRR}$ replicon, $\mathrm{Gm}^{\mathrm{r}}$ & Lagendijk et al. 2010 \\
\hline pKD13 & Broad-host-range plasmid, $\mathrm{Km}^{\mathrm{r}}$ cassette & Datsenko and Wanner 2000 \\
\hline pRSFRedTER & $\begin{array}{l}\text { Broad-host-range plasmid, phage } \lambda \text { gam, bet and exo genes under control of } \mathrm{P}_{\text {lacuv5 }} \text {, } \\
\text { sacB gene, } \mathrm{Cm}^{\mathrm{r}}\end{array}$ & Katashkina et al. 2009 \\
\hline pBRRMCS-5 & Promoterless broad-host-range vector, $\mathrm{Gm}^{\mathrm{r}}$ & Kovach et al. 1995 \\
\hline pBRR-tssA & pBRRMCS-5 harboring wild-type $t s s A$, inclusive of a 528-bp upstream region, $\mathrm{Gm}^{\mathrm{r}}$ & This study \\
\hline pBRR-tssD & pBRRMCS-5 harboring wild-type $t s s D$, inclusive of a 540-bp upstream region, $\mathrm{Gm}^{\mathrm{r}}$ & This study \\
\hline
\end{tabular}

\footnotetext{
${ }^{\mathrm{a}} \mathrm{Cm}^{\mathrm{r}}, \mathrm{Km}^{\mathrm{r}}$, and $\mathrm{Gm}^{\mathrm{r}}=$ resistant to choloramphenicol, kanamycin, and gentamycin, respectively.
} 
from Zymo Research Corp., Orange, CA, U.S.A.). Plasmid constructions were first established in $E$. coli $\mathrm{DH} 5 \alpha$ and then transferred to $P$. ananatis strains. Electrocompetent cells were prepared and transformed according to published procedures for E. coli (Cohen et al. 1972) and P. ananatis (Katashkina et al. 2009). Polymerase chain reaction (PCR) assays were performed with SuperTherm DNA polymerase (Whitehead Scientific, Cape Town, South Africa) and PCR amplicons were purified with the DNA Clean and Concentrator kit (Zymo Research Corp.). Primers used in this study were designed from the $P$. ananatis LMG $2665^{\mathrm{T}}$ genome sequence and obtained from Inqaba Biotechnical Industries (Pretoria, South Africa). Southern blot hybridization was performed using the DIG-High Prime DNA labeling and detection starter kit (Roche Diagnostics). Nucleotide sequencing was performed with the ABI PRISM BigDye terminator v.3.1 cycle sequencing ready reaction kit (Applied Biosystems, Foster City, CA, U.S.A.), followed by resolution on an ABI PRISM 3100 Genetic Analyzer (Applied Biosystems), in accordance with the manufacturer's instructions. All plasmid constructs were verified by restriction endonuclease digestion and by nucleotide sequencing.

\section{Generation of $P$. ananatis LMG $2665^{\mathrm{T}}$ mutant strains.}

Mutant strains with deletions of T6SS-1 (N454_00602 to N454_00638), T6SS-3 (N454_0002 to N454_0008), tssA (N454_00632), or tssD (N454_00629; hcp) were constructed with the $\lambda$ Red-recombineering method, as described previously (Datsenko and Wanner 2000; Katashkina et al. 2009). Gene cluster and single-gene disruption cassettes were first constructed by an overlap-extension PCR protocol (Shevchuk et al. 2004). Briefly, 400- to 900-bp DNA fragments contiguous to the $5^{\prime}$ and $3^{\prime}$ ends of targeted genes were PCR amplified by using LMG $2665^{\mathrm{T}}$ chromosomal DNA template and the appropriate $F_{u p} / R_{\text {up }}$-kan and $F_{\text {down }}-k a n / R_{\text {down }}$ primers (Supplementary Table S1; Supplementary Fig. S1). Each of the $\mathrm{R}_{\mathrm{up}}-\mathrm{kan}$ and $F_{\text {down }}$-kan primers contained 20 nucleotides that are homologous to the $5^{\prime}$ and $3^{\prime}$ termini, respectively, of a kanamycin resistance gene. Plasmid pkD13 was used as template to amplify the kanamycin resistance gene with flanking regions homologous to the target gene using the appropriate F-Kan and $\mathrm{R}-$ Kan primers. In a second PCR, $20 \mathrm{ng}$ of each of the purified amplified DNA fragments were mixed and the fused DNA fragments were obtained by overlap-extension PCR with the appropriate $\mathrm{F}_{\mathrm{up}} / \mathrm{R}_{\text {down }}$ primers.

To enable $\lambda$ Red-dependent integration of the fused DNA fragments, the purified disruption cassettes were introduced into electrocompetent $P$. ananatis LMG $2665^{\mathrm{T}}$ carrying the plasmid pRSFRedTER, which expresses the $\lambda$ Red recombinase system and encodes a $s a c B$ counter-selection gene (Katashkina et al. 2009). An overnight culture of $P$. ananatis LMG $2665^{\mathrm{T}}$ (pRSFRedTER) was diluted 100-fold in LB broth supplemented with chloramphenicol and $1.5 \mathrm{mM}$ isopropyl- $\beta$-Dthiogalactopyranoside to induce expression of the $\lambda$ recombinase system. The culture was grown to an $\mathrm{OD}_{600}$ of 0.5 at $32^{\circ} \mathrm{C}$. Bacteria were then made electrocompetent and transformed with 300 to $500 \mathrm{ng}$ of the corresponding purified PCR-generated disruption cassettes. The resulting strains were selected by kanamycin resistance on LB agar. Selected strains were cured from the pRSFRedTER plasmid DNA by streaking on LB agar containing $10 \%$ (wt/vol) sucrose, and loss of the plasmid DNA was confirmed by streaking the strains on agar containing chloramphenicol. Allelic replacement in mutant strains that were chloramphenicol sensitive but kanamycin resistant was confirmed by PCR with primers flanking the deletion sites ( $\mathrm{F}_{\text {up }}$-out/ $\mathrm{R}_{\mathrm{down}}$-out) and sequencing of the amplicons, as well as by Southern blot hybridization (data not shown).
Complementation of $P$. ananatis LMG $2665^{\mathrm{T}} \Delta t s s A$ and $\Delta t s s D$ knockout mutants.

To complement the $t s s A$ and $t s s D$ genes, the full-length $t s s A$ $(1.023 \mathrm{~kb})$ and $t s s D(483 \mathrm{bp})$ genes, together with upstream regions to include putative promoters (up to $540 \mathrm{bp}$ ), were PCR amplified using $P$. ananatis LMG $2665^{\mathrm{T}}$ genomic DNA as template and the appropriate primers. The amplicons were treated with Klenow polymerase, blunt-end cloned into the promoterless broad-host-range cloning vector pBRRMCS-5, then transformed into $E$. coli DH5 $\alpha$. The complementation plasmids pBRR-tss $A$ and pBRR-tss $D$ were extracted from $E$. coli and electroporated into the corresponding $P$. ananatis mutant strains, and complemented strains were selected by gentamycin resistance on LB agar.

\section{Pathogenicity assays.}

Pathogenicity of $P$. ananatis wild-type and mutant strains was determined in onion plants, as described previously (Goszczynska et al. 2006; Morohoshi et al. 2007). In each test, at least four leaves of 6-week-old onion plants (A. cepa 'Texas grando') were inoculated with $3 \mu$ of the inoculum $\left(6.2 \times 10^{6}\right.$ $\mathrm{CFU} / \mathrm{ml}$ ) under the epidermis of the leaf. Sterile $\mathrm{dH}_{2} \mathrm{O}$ was included in the assay as a negative control. On average, 20 onion plants were inoculated per strain and each experiment was repeated three independent times. The plants were maintained in the greenhouse during the evaluation period at a temperature of 25 to $28^{\circ} \mathrm{C}$ under natural day and night cycles. Plants were visually inspected daily for development of disease symptoms. At 3 days postinoculation, the number of inoculated wilted (dead) leaves per plant for each strain was recorded and the average percentage of dead leaves in all three biological repeats was calculated.

\section{Bacterial competition assays.}

Bacterial strains used for the competition studies are provided in Supplementary Table S2. The competition assays were carried out with a slightly modified version of a protocol described by MacIntyre and associates (2010). To ensure selection of competitor cells for counting, each of the bacterial strains was transformed with plasmid pMP7605 to confer gentamycin resistance (Kovach et al. 1995). For competition assays, each strain was grown overnight in LB broth supplemented with antibiotic, then collected and washed twice in sterile LB broth $(7,000 \times g$, $2 \mathrm{~min}$ ). The cell suspensions were normalized to an $\mathrm{OD}_{600}$ of 0.1 and mixed at a ratio of $1: 1$ with either the $P$. ananatis wild-type or mutant strains. The mixture $(20 \mu \mathrm{l})$ was spotted on LB agar and incubated overnight at $32^{\circ} \mathrm{C}$ for all targeted bacteria analyzed, excepting Pectobacterium spp., which were cocultured with $P$. ananatis at $28^{\circ} \mathrm{C}$. After incubation, the bacteria were recovered from the agar plates and suspended in $1 \mathrm{ml}$ of sterile LB broth, and serial dilutions were plated in duplicate on LB agar supplemented with gentamycin.

\section{Statistical analyses.}

Statistical significance of the data obtained in bacterial competition assays was evaluated by making use of an unpaired, two-tailed Student's $t$ test using JMP software (v.5; SAS Institute Inc., Cary, NC, U.S.A.). $P$ values of less than 0.05 were considered to be significant.

\section{ACKNOWLEDGMENTS}

This study was supported by the University of Pretoria, the National Research Foundation (NRF), the Forestry and Agricultural Biotechnology Institute (FABI), the Tree Protection Co-operative Programme (TPCP), the NRF/Department of Science and Technology Centre of Excellence in Tree Health Biotechnology (CTHB), and the THRIP support program of the 
Department of Trade and Industry, South Africa. I. K. Toth is supported by the Scottish Government Rural and Environment Research and Analysis Directorate (RERAD).

\section{LITERATURE CITED}

Aschtgen, M. S., Bernard, C. S., De Bentzmann, S., Lloubés, R., and Cascales, E. 2008. SciN is an outer membrane lipoprotein required for type VI secretion in enteroaggregative Escherichia coli. J. Bacteriol. 190:7523-7531.

Backert, S., and Meyer, T. F. 2006. Type IV secretion systems and their effectors in bacterial pathogenesis. Curr. Opin. Microbiol. 9:207217.

Ballister, E. R., Lai, A. H., Zuckermann, R. N., Cheng, Y., and Mougous, J. D. 2008. In vitro self-assembly of tailorable nanotubes from a simple protein building block. Proc. Natl. Acad. Sci. U.S.A. 105:37333738 .

Basler, M., Pilhofer, M., Henderson, G. P., Jensen, G. J., and Mekalanos, J. J. 2012. Type VI secretion requires a dynamic contractile phage taillike structure. Nature 483:182-186.

Bingle, L. E. H., Bailey, C. M., and Pallen, M. J. 2008. Type VI secretion: A beginner's guide. Curr. Opin. Microbiol. 11:3-8.

Blondel, C. J., Yang, H.-J., Castro, B., Chiang, S., Toro, C. S., Zaldívar, M., Contreras, I., Andrews-Polymenis, H. L., and Santiviago, C. A. 2010. Contribution of the type VI secretion system encoded in SPI-19 to chicken colonization by Salmonella enterica serotypes Gallinarum and Enteritidis. PLoS One 5:e11724.

Bönemann, G., Pietrosiuk, A., Diemand, A., Zentgraf, H., and Mogk, A. 2009. Remodelling of VipA/VipB tubules by ClpV-mediated threading is crucial for type VI protein secretion. EMBO (Eur. Mol. Biol. Organ.) J. 28:315-325.

Boyer, F., Fichant, G., Berthod, J., Vandenbrouck, Y., and Attree, I. 2009. Dissecting the bacterial type VI secretion system by a genome wide in silico analysis: What can be learned from available microbial genomic resources? BMC Genomics 10:104.

Carruthers, M. D., Nicholson, P. A., Tracy, E. N., and Munson, R. S., Jr. 2013. Acinetobacter baumannii utilizes a type VI secretion system for bacterial competition. PLoS One 8:e59388.

Cascales, E. 2008. The type VI secretion toolkit. EMBO (Eur. Mol. Biol Organ.) Rep. 9:735-741.

Cascales, E., and Cambillau, C. 2012. Structural biology of type VI secretion systems. Philos. Trans. R. Soc. Lond. B Biol. Sci. 367: 1102-1111.

Chaudhuri, R. R., Morgan, E., Peters, S. E., Pleasance, S. J., Hudson, D. L., Davies, H. M., Wang, J., van Diemen, P. M., Buckley, A. M., Bowen, A. J., Pullinger, G. D., Turner, D. J., Langridge, G. C., Turner, A. K., Parkhill, J., Charles, I. G., Maskell, D. J., and Stevens, M. P. 2013. Comprehensive assignment of roles for Salmonella typhimurium genes in intestinal colonization of food-producing animals. PLoS Genet. 9: e1003456.

Chou, S., Bui, N. K., Russell, A. B., Lexa, K. W., Gardiner, T. E., LeRoux, M., Vollmer, W., and Mougous, J. D. 2012. Structure of a peptidoglycan amidase effector targeted to gram-negative bacteria by the type VI secretion system. Cell Reports 1:656-664.

Cianciotto, N. P. 2005. Type II secretion: A protein secretion system for all seasons. Trends Microbiol. 13:581-588.

Cohen, S. N., Chang, A. C. Y., and Hsu, L. 1972. Nonchromosomal antibiotic resistance in bacteria: Genetic transformation of Escherichia coli by R-factor DNA. Proc. Natl. Acad. Sci. U.S.A. 69:2110-2114.

Cornelis, G. R. 2006. The type III secretion injectisome. Nat. Rev. Microbiol. 4:811-825.

Coulthurst, S. J. 2013. The Type VI secretion system - a widespread and versatile cell targeting system. Res. Microbiol. 164:640-654.

Coutinho, T. A., and Venter, S. N. 2009. Pantoea ananatis: An unconventional plant pathogen. Mol. Plant Pathol. 10:325-335.

Datsenko, K. A., and Wanner, B. L. 2000. One-step inactivation of chromosomal genes in Escherichia coli K-12 using PCR products. Proc. Natl. Acad. Sci. U.S.A. 97:6640-6645

De Maayer, P., Venter, S. N., Kamber, T., Duffy, B., Coutinho, T. A., and Smits, T. H. 2011. Comparative genomics of the Type VI secretion systems of Pantoea and Erwinia species reveals the presence of putative effector islands that may be translocated by the VgrG and Hcp proteins. BMC Genomics 12:576.

de Pace, F., Nakazato, G., Pacheco, A., de Paiva, J. B., Sperandio, V., and da Silveira, W. D. 2010. The type VI secretion system plays a role in type 1 fimbria expression and pathogenesis of an avian pathogenic Escherichia coli strain. Infect. Immun. 78:4990-4998.
Decoin, V., Barbey, C., Bergeau, D., Latour, X., Feuilloley, M. G. J., Orange, N., and Merieau, A. 2014. A type VI secretion system is involved in Pseudomonas fluorescens bacterial competition. PLoS One 9:e89411

Dong, T. G., Ho, B. T., Yoder-Himes, D. R., and Mekalanos, J. J. 2013 Identification of T6SS-dependent effector and immunity proteins by Tn-seq in Vibrio cholerae. Proc. Natl. Acad. Sci. U.S.A. 110:26232628.

Durand, E., Zoued, A., Spinelli, S., Watson, P. J., Aschtgen, M. S., Journet, L., Cambillau, C., and Cascales, E. 2012. Structural characterization and oligomerization of the TssL protein, a component shared by bacterial type VI and type IVb secretion systems. J. Biol. Chem. 287: $14157-14168$

Economou, A., Christie, P. J., Fernandez, R. C., Palmer, T., Plano, G. V., and Pugsley, A. P. 2006. Secretion by numbers: Protein traffic in prokaryotes. Mol. Microbiol. 62:308-319.

English, G., Trunk, K., Rao, V. A., Srikannathasan, V., Hunter, W. N., and Coulthurst, S. J. 2012. New secreted toxins and immunity proteins encoded within the type VI secretion system gene cluster of Serratia marcescens. Mol. Microbiol. 86:921-936.

Felisberto-Rodrigues, C., Durand, E., Aschtgen, M. S., Blangy, S., OrtizLombardia, M., Douzi, B., Cambillau, C., and Cascales, E. 2011. Towards a structural comprehension of bacterial type VI secretion systems: Characterization of the TssJ-TssM complex of an Escherichia coli pathovar. PLoS Pathog. 7:e1002386.

Filloux, A., Hachani, A., and Bleves, S. 2008. The bacterial type VI secretion machine: Yet another player for protein transport across membranes. Microbiology 154:1570-1583.

Fritsch, M. J., Trunk, K., Diniz, J. A., Guo, M., Trost, M., and Coulthurst, S. J. 2013. Proteomic identification of novel secreted antibacterial toxins of the Serratia marcescens type VI secretion system. Mol. Cell. Proteomics 12:2735-2749.

Gallegos-Robles, M. A., Morales-Loredo, A., Alvarez-Ojeda, G., Vega-P, A., Chew-M, Y., Velarde, S., and Fratamico, P. 2008. Identification of Salmonella serotypes isolated from cantaloupe and chile pepper production systems in Mexico by PCR-restriction fragment length polymorphism. J. Food Prot. 71:2217-2222.

Gerlach, R. G., and Hensel, M. 2007. Protein secretion systems and adhesins: The molecular armory of gram-negative pathogens. Int. J. Med. Microbiol. 297:401-415.

Gitaitis, R. D., and Gay, J. D. 1997. First report of a leaf blight seed stalk rot, and bulb decay of onion by Pantoea ananas in Georgia. Plant Dis $81: 1096$.

Goszczynska, T., Moloto, V. M., Venter, S. N., and Coutinho, T. A. 2006. Isolation and identification of Pantoea ananatis from onion seed in South Africa. Seed Sci. Technol. 34:655-668.

Goszczynska, T., Botha, W. J., Venter, S. N., and Coutinho, T. A. 2007. Isolation and identification of the causal agent of brown stalk rot, a new disease of maize in South Africa. Plant Dis. 91:711-718.

Gu, G., Hu, J., Cevallos-Cevallos, J. M., Richardson, S. M., Bartz, J. A., and van Bruggen, A. H. C. 2011. Internal colonization of Salmonella enterica serovar Typhimurium in tomato plants. PLoS One 6:e27340.

Haapalainen, M., Mosorin, H., Dorati, F., Wu, R.-F., Roine, E., Taira, S., Nissinen, R., Mattinen, L., Jackson, R., Pirhonen, M., and Lin, N. C. 2012. Hcp2, a secreted protein of the phytopathogen Pseudomonas syringae pv. tomato DC3000, is required for fitness for competition against bacteria and yeasts. J. Bacteriol. 194:4810-4822.

Holland, I. B. 2010. The extraordinary diversity of bacterial protein secretion mechanisms. Methods Mol. Biol. 619:1-20.

Hood, R. D., Singh, P., Hsu, F., Güvener, T., Carl, M. A., Trinidad, R. R., Silverman, J. M., Ohlson, B. B., Hicks, K. G., Plemel, R. L., Li, M., Schwarz, S., Wang, W. Y., Merz, A. J., Goodlett, D. R., and Mougous, J. D. 2010. A type VI secretion system of Pseudomonas aeruginosa targets a toxin to bacteria. Cell Host Microbe 7:25-37.

Hueck, C. J. 1998. Type III protein secretion systems in bacterial pathogens of animals and plants. Microbiol. Mol. Biol. Rev. 62:379-433.

Jobichen, C., Chakraborty, S., Li, M., Zheng, J., Joseph, L., Mok, Y.-K., Leung, K. Y., and Sivaraman, J. 2010. Structural basis for the secretion of EvpC: A key type VI secretion system protein from Edwardsiella tarda. PLoS One 5:e12910.

Kanamaru, S. 2009. Structural similarity of tailed phages and pathogenic bacterial secretion systems. Proc. Natl. Acad. Sci. U.S.A. 106: 4067-4068

Kapitein, N., and Mogk, A. 2013. Deadly syringes: Type VI secretion system activities in pathogenicity and interbacterial competition. Curr. Opin. Microbiol. 16:52-58.

Kapitein, N., Bönemann, G., Pietrosiuk, A., Seyffer, F., Hausser, I., Locker, J. K., and Mogk, A. 2013. ClpV recycles VipA/VipB tubules and 
prevents non-productive tubule formation to ensure efficient type VI protein secretion. Mol. Microbiol. 87:1013-1028.

Katashkina, J. I., Hara, Y., Golubeva, L. I., Andreeva, I. G., Kuvaeva, T. M., and Mashko, S. V. 2009. Use of the $\lambda$ Red-recombineering method for genetic engineering of Pantoea ananatis. BMC Mol. Biol. 10:34.

Koskiniemi, S., Lamoureux, J. G., Nikolakakis, K. C., t'Kint de Roodenbeke, C., Kaplan, M. D., Low, D. A., and Hayes, C. S. 2013. Rhs proteins from diverse bacteria mediate intercellular competition. Proc. Natl. Acad. Sci. U.S.A. 110:7032-7037.

Kovach, M. E., Elzer, P. H., Hill, D. S., Robertson, G. T., Farris, M. A., Roop, R. M., 2nd, and Peterson, K. M. 1995. Four new derivatives of the broad-host-range cloning vector pBBR1MCS, carrying different antibiotic-resistance cassettes. Gene 166:175-176.

Kung, V. L., Khare, S., Stehlik, C., Bacon, E. M., Hughes, A. J., and Hauser, A. R. 2012. An rhs gene of Pseudomonas aeruginosa encodes a virulence protein that activates the inflammasome. Proc. Natl. Acad. Sci. U.S.A. 109:1275-1280.

Lagendijk, E. L., Validov, S., Lamers, G. E. M., de Weert, S., and Bloemberg, G. V. 2010. Genetic tools for tagging gram-negative bacteria with mCherry for visualization in vitro and in natural habitats, biofilm and pathogenicity studies. FEMS (Fed. Eur. Microbiol. Soc.) Microbiol. Lett. 305:81-90.

Leiman, P. G., Basler, M., Ramagopal, U. A., Bonanno, J. B., Sauder, J. M., Pukatzki, S., Burley, S. K., Almo, S. C., and Mekalanos, J. J. 2009. Type VI secretion apparatus and phage tail-associated protein complexes share a common evolutionary origin. Proc. Natl. Acad. Sci. U.S.A. 106: 4154-4159.

Lin, J.-S., Ma, L.-S., and Lai, E.-M. 2013. Systematic dissection of the Agrobacterium type VI secretion system reveals machinery and secreted components for subcomplex formation. PLoS One 8:e67647.

Liu, H., Coulthurst, S. J., Pritchard, L., Hedley, P. E., Ravensdale, M., Humphris, S., Burr, T., Takle, G., Brurberg, M. B., Birch, P. R., Salmond, G. P. C., and Toth, I. K. 2008. Quorum sensing coordinates brute force and stealth modes of infection in the plant pathogen Pectobacterium atrosepticum. PLoS Pathog. 4:e1000093.

Lossi, N. S., Dajani, R., Freemont, P., and Filloux, A. 2011. Structurefunction analysis of HsiF, a gp25-like component of the type VI secretion system, in Pseudomonas aeruginosa. Microbiology 157:3292-3305.

Lossi, N. S., Manoli, E., Förster, A., Dajani, R., Pape, T., Freemont, P., and Filloux, A. 2013. The HsiB1C1 (TssB-TssC) complex of the Pseudomonas aeruginosa type VI secretion system forms a bacteriophage tail sheathlike structure. J. Biol. Chem. 288:7536-7548.

Ma, A. T., and Mekalanos, J. J. 2010. In vivo actin cross-linking induced by Vibrio cholerae type VI secretion system is associated with intestinal inflammation. Proc. Natl. Acad. Sci. U.S.A. 107:4365-4370.

Ma, L. S., Narberhaus, F., and Lai, E. M. 2012. IcmF family protein TssM exhibits ATPase activity and energizes type VI secretion. J. Biol. Chem. 287:15610-15621.

MacIntyre, D. L., Miyata, S. T., Kitaoka, M., and Pukatzki, S. 2010. The Vibrio cholerae type VI secretion system displays antimicrobial properties. Proc. Natl. Acad. Sci. U.S.A. 107:19520-19524.

Mergaert, J., Verdonck, L., and Kersters, K. 1993. Transfer of Erwinia ananas (synonym, Erwinia uredovora) and Erwinia stewartii to the genus Pantoea emend. as Pantoea ananas (Serrano 1928) comb. nov. and Pantoea stewartii (Smith 1898) comb. nov., respectively, and description of Pantoea stewartii subsp. indologenes subsp. nov. Int. J. Syst. Bacteriol. 43:162-173.

Miyata, S. T., Kitaoka, M., Brooks, T. M., McAuley, S. B., and Pukatzki, S 2011. Vibrio cholerae requires the type VI secretion system virulence factor VasX to kill Dictyostelium discoideum. Infect. Immun. 79: 2941-2949.

Morohoshi, T., Nakamura, Y., Yamazaki, G., Ishida, A., Kato, N., and Ikeda, T. 2007. The plant pathogen Pantoea ananatis produces Nacylhomoserine lactone and causes center rot disease of onion by quorum sensing. J. Bacteriol. 189:8333-8338.

Morohoshi, T., Ogata, Y., and Ikeda, T. 2011a. Cell aggregation is negatively regulated by $\mathrm{N}$-acylhomoserine lactone-mediated quorum sensing in Pantoea ananatis SK-1. J. Biosci. Bioeng. 112:566-569.

Morohoshi, T., Oseki, K., and Ikeda, T. 2011b. Exopolysaccharide production is influenced by sugars, $\mathrm{N}$-acylhomoserine lactone, and transcriptional regulators RcsA and RcsB, but does not affect pathogenicity in the plant pathogen Pantoea ananatis. Biosci. Biotechnol. Biochem. 75:997-999.

Mougous, J. D., Cuff, M. E., Raunser, S., Shen, A., Zhou, M., Gifford C. A., Goodman, A. L., Joachimiak, G., Ordoñez, C. L., Lory, S., Walz, T., Joachimiak, A., and Mekalanos, J. J. 2006. A virulence locus of Pseudomonas aeruginosa encodes a protein secretion apparatus. Science 312:1526-1530.
Mougous, J. D., Gifford, C. A., Ramsdell, T. L., and Mekalanos, J. J. 2007. Threonine phosphorylation post-translationally regulates protein secretion in Pseudomonas aeruginosa. Nat. Cell Biol. 9:797-803.

Murdoch, S. L., Trunk, K., English, G., Fritsch, M. J., Pourkarimi, E., and Coulthurst, S. J. 2011. The opportunistic pathogen Serratia marcescens utilizes type VI secretion to target bacterial competitors. J. Bacteriol. 193:6057-6069.

Pukatzki, S., Ma, A. T., Sturtevant, D., Krastins, B., Sarracino, D., Nelson, W. C., Heidelberg, J. F., and Mekalanos, J. J. 2006. Identification of a conserved bacterial protein secretion system in Vibrio cholerae using the Dictyostelium host model system. Proc. Natl. Acad. Sci. U.S.A. 103: 1528-1533.

Pukatzki, S., Ma, A. T., Revel, A. T., Sturtevant, D., and Mekalanos, J. J. 2007. Type VI secretion system translocates a phage tail spike-like protein into target cells where it cross-links actin. Proc. Natl. Acad. Sci. U.S.A. 104:15508-15513.

Records, A. R. 2011. The type VI secretion system: A multipurpose delivery system with a phage-like machinery. Mol. Plant-Microbe Interact. 24:751-757.

Russell, A. B., Hood, R. D., Bui, N. K., LeRoux, M., Vollmer, W., and Mougous, J. D. 2011. Type VI secretion delivers bacteriolytic effectors to target cells. Nature 475:343-347.

Russell, A. B., Singh, P., Brittnacher, M., Bui, N. K., Hood, R. D., Carl, M. A., Agnello, D. M. K., Schwarz, S., Goodlett, D. R., Vollmer, W., and Mougous, J. D. 2012. A widespread bacterial type VI secretion effector superfamily identified using a heuristic approach. Cell Host Microbe 11: 538-549.

Sambrook, J., and Russell, D. W. 2001. Molecular Cloning: A Laboratory Manual. Cold Spring Harbor Laboratory Press, Cold Spring Harbor, NY, U.S.A.

Sandkvist, M. 2001. Biology of type II secretion. Mol. Microbiol. 40: 271-283.

Sarris, P. F., Trantas, E. A., Skandalis, N., Tampakaki, A. P., Kapanidou, M., Kokkinidis, M., and Panopoulos, N. J. 2012. Phytobacterial type VI secretion system-Gene distribution, phylogeny, structure and biological functions. Pages 53-84 in: Plant Pathology. C. J. Cumagun, ed. InTech, Croatia.

Schell, M. A., Ulrich, R. L., Ribot, W. J., Brueggemann, E. E., Hines, H. B., Chen, D., Lipscomb, L., Kim, H. S., Mrazek, J., Nierman, W. C., and Deshazer, D. 2007. Type VI secretion is a major virulence determinant in Burkholderia mallei. Mol. Microbiol. 64:1466-1485.

Schwarz, S., Hood, R. D., and Mougous, J. D. 2010a. What is type VI secretion doing in all those bugs? Trends Microbiol. 18:531-537.

Schwarz, S., West, T. E., Boyer, F., Chiang, W. C., Carl, M. A., Hood, R. D., Rohmer, L., Tolker-Nielsen, T., Skerrett, S. J., and Mougous, J. D. 2010b. Burkholderia type VI secretion systems have distinct roles in eukaryotic and bacterial cell interactions. PLoS Pathog. 6:e1001068.

Serrano, F. B. 1928. Bacterial fruitlet brown-rot of pineapple in the Philippines. Philip. J. Sci. 36:271-305.

Sessitsch, A., Reiter, B., and Berg, G. 2004. Endophytic bacterial communities of field-grown potato plants and their plant-growth-promoting and antagonistic abilities. Can. J. Microbiol. 50:239-249.

Shalom, G., Shaw, J. G., and Thomas, M. S. 2007. In vivo expression technology identifies a type VI secretion system locus in Burkholderia pseudomallei that is induced upon invasion of macrophages. Microbiology 153:2689-2699.

Shevchuk, N. A., Bryksin, A. V., Nusinovich, Y. A., Cabello, F. C., Sutherland, M., and Ladisch, S. 2004. Construction of long DNA molecules using long PCR-based fusion of several fragments simultaneously. Nucleic Acids Res. 32:e19.

Shneider, M. M., Buth, S. A., Ho, B. T., Basler, M., Mekalanos, J. J., and Leiman, P. G. 2013. PAAR-repeat proteins sharpen and diversify the type VI secretion system spike. Nature 500:350-353.

Shrivastava, S., and Mande, S. S. 2008. Identification and functional characterization of gene components of Type VI Secretion system in bacterial genomes. PLoS One 3:e2955.

Shyntum, D. Y., Venter, S. N., Moleleki, L. N., Toth, I., and Coutinho, T. A. 2014. Comparative genomics of type VI secretion systems in strains of Pantoea ananatis from different environments. BMC Genomics 15:163.

Silverman, J. M., Brunet, Y. R., Cascales, E., and Mougous, J. D. 2012 Structure and regulation of the type VI secretion system. Annu. Rev. Microbiol. 66:453-472.

Suarez, G., Sierra, J. C., Sha, J., Wang, S., Erova, T. E., Fadl, A. A., Foltz, S. M., Horneman, A. J., and Chopra, A. K. 2008. Molecular characterization of a functional type VI secretion system from a clinical isolate of Aeromonas hydrophila. Microb. Pathog. 44:344-361.

Suarez, G., Sierra, J. C., Erova, T. E., Sha, J., Horneman, A. J., and Chopra, A. K. 2010. A type VI secretion system effector protein, VgrG1, from 
Aeromonas hydrophila that induces host cell toxicity by ADP ribosylation of actin. J. Bacteriol. 192:155-168.

Toth, I. K., Bell, K. S., Holeva, M. C., and Birch, P. R. J. 2003. Soft rot erwiniae: From genes to genomes. Mol. Plant Pathol. 4:17-30.

Walcott, R. R., Gitaitis, R. D., Castro, A. C., Sanders, F. H., and Diaz-Perez, J. C. 2002. Natural infestation of onion seed by Pantoea ananatis, causal agent of center rot. Plant Dis. 86:106-111.

Weber, B. S., Miyata, S. T., Iwashkiw, J. A., Mortensen, B. L., Skaar, E. P., Pukatzki, S., and Feldman, M. F. 2013. Genomic and functional analysis of the type VI secretion system in Acinetobacter. PLoS One 8:e55142.

Wu, H. Y., Chung, P. C., Shih, H. W., Wen, S. R., and Lai, E. M. 2008. Secretome analysis uncovers an Hcp-family protein secreted via a type VI secretion system in Agrobacterium tumefaciens. J. Bacteriol. 190: 2841-2850.
Zhang, D., de Souza, R. F., Anantharaman, V., Iyer, L. M., and Aravind, L. 2012. Polymorphic toxin systems: Comprehensive characterization of trafficking modes, processing, mechanisms of action, immunity and ecology using comparative genomics. Biol. Direct 7:18

Zheng, J., and Leung, K. Y. 2007. Dissection of a type VI secretion system in Edwardsiella tarda. Mol. Microbiol. 66:1192-1206.

Zheng, J., Ho, B., and Mekalanos, J. J. 2011. Genetic analysis of antiamoebae and anti-bacterial activities of the type VI secretion system in Vibrio cholerae. PLoS One 6:e23876.

Zoued, A., Durand, E., Bebeacua, C., Brunet, Y. R., Douzi, B., Cambillau, C., Cascales, E., and Journet, L. 2013. TssK is a trimeric cytoplasmic protein interacting with components of both phage-like and membrane anchoring complexes of the type VI secretion system. J. Biol. Chem. 288:27031-27041. 